\title{
Contesting Within Order? China, socialisation, and international practice
}

\begin{abstract}
Debates on China's relationship to global order, and particularly international institutions and considerations of humanitarian intervention, centre on a (false) dichotomy that China is either a status-quo or revisionist power. Both sides of this debate have ample empirical evidence to support their arguments and they tend towards conclusions that China's behaviour and preferences lie in the space in between these two positions. It is important to consider how China presents a contest to international order from with international institutions.

This article examines the question: What is China being socialised into? Drawing on the international practices literature, this paper unpacks the types of norms that China may be being socialised into. It makes the argument that China has been successfully socialised into the practices of international institutions - the ways the bureaucracies work and can be used to achieve political goals - and pluralist-liberal global norms, but incompletely into solidarist liberal norms that have emerged in the post-2005 era. In this China has focused on state-tostate objectives of sanctions. This is particularly evident in its weak implementation of the sanctions against luxury goods aimed at coercing individuals within the regime rather than the state.

In making this argument, the paper explores a critical case of China's engagement with UN sanctions. This case is important because it demonstrates - rather than either or simultaneously both China's challenge to the world order and its support of it. In presenting this case the research draws on fieldwork from two periods of participant observation at the UN in New York and utilises elite interviews and document analysis.
\end{abstract}

Key words: China, International Order, International Practice, Sanctions, North Korea.

Author Details:

Dr Catherine JONES

Lecturer, University of St Andrews

Bio: Catherine Jones is a Lecturer at the University of St Andrews. Her research focuses on the ability of Asian states to present normative contests to the existing international order. Her first monograph was published by Palgrave in 2018, entitled 'China's challenge to liberal norms'. Her research has also been published in International Politics, The Pacific Review and Pacific Focus. 


\section{Introduction}

International institutions stabilise and maintain a particular international order (Author, 2018). ${ }^{1}$ As a result of this role, some authors have claimed that it will be difficult for rising powers to rewrite or revise global order (for example, Ikenberry, 2001, 2008, 2009; Medeiros, 2005). However, international institutions do not only provide stability but are a forum for contesting norms, shared understandings, and practices. Although the degree of potential change within institutions is limited by of institutional stickiness (March and Olsen, 2004; Sending 2002:449), John Ruggie (1998:84) and Robert Gilpin (1982:45) have argued that changes within institutions are possible. Despite this acknowledgement the potential for states to amend international order from within the structures of international institutions remains understudied. $^{2}$ This is even true in the case of perhaps the most studied international institutions in the world - the United Nations Security Council (UNSC). ${ }^{3}$ In examining the opportunities within institutions, it is apparent that one place for seeking to affect change is through amendments to the rules and day-to-day processes that would otherwise provide stability. Hence, in looking within international institutions and behind the large fora that occupy the centre stage of studies, it is apparent that there are many layers through which changes - that is gradual and incremental - can be pursued.

In considering China's ability to shape or renegotiate international order within institutions, the focus has rightly been on the big political forums, such as the Security Council (Kim, 1979; Kent, 2009; Wuthnow, 2013), the Human Rights Council (Kent, 2010; Sceats and Breslin, 2012), the World Trade Organisation and the International Monetary Fund (Ferdinand and Wang, 2013; Economy and Okensberg, 1999), through engagement with practical implementation of norms such as peacekeeping operations (for example, Hirono, 2011; Reilly and Gill, 2000). In these studies, the questions raised hinge on whether China maintains the 'status quo' (Johnston 2003; Buzan, 2010), has become 'socialised' to international norms (Foot and Walter, 2012; Johnston, 2008), or has become a norm-maker rather than a normtaker (Lee, Chan and Chan, 2011; Reilly, 2012; Clark 2014). Whilst these studies are vital to capturing an essential element in China's global engagements and crucially setting out whether China has a project or plan for changing international order, these works frequently respond to questions phrased as a dichotomy between acceptance and rejection. And yet, these texts tend to conclude that China's relationship with international (liberal) norms lie somewhere in between acceptance and rejection, highlighting that changes are gradual and incremental. It is 
now essential to expand and deepen these conclusions and explore the questions enabled by these previous studies, by looking at alternative locations for changes to emerge.

This article initiates this process by raising the question: What is China being socialised into? In these previous works, the subject of inquiry has focused on whether China seeks to amend the ideas of international order (sovereignty, international aid, intervention). But, none of these works has questioned at what level China may (not) be socialised. Nor, indeed, have they considered the various types of international norms that China may internalise: first order/second order; meta/interstitial; pluralist/liberal. As a result, the research question here demonstrates that in the case of sanctions against North Korea, there are a range of norms that China could be argued to have been socialised to, beyond non-proliferation, for example norms surrounding the appropriate use of sanctions to achieve certain aims, or the norms of procedure in challenging international order.

This research is made possible by, and contributes to, the expansion of the literature exploring the detail of China's institutional engagements. Over the past decade, scholars have sought to explore more detail different issue areas - most notably in China's engagement with international economic governance, particularly in the light of the emergence of the Asian Infrastructure Investment Bank (AIIB) and in understanding the implications of fragmentation of the domestic foreign policy architecture. For example, Wang and $\mathrm{Hu}$, specify the importance of Chinese companies in shaping 'China's' engagement with these financial institutions and the 'boomerang effects' these engagements on foreign policy making and internal governance in China (2017:832; also, Wilson, 2019:159-164). Similarly, Beeson and Li have investigated the connections between debates on global governance within China to the "process of policy formulation, experimentation and articulation" (2016:3) and therefore reflect the ad-hoc nature of China's global engagement. Jones and Hameiri, have identified that it is the internal fragmentation within China's internal governance structures and "contestation among these agencies that will determine China's real challenge to the global governance of development, and this challenge will often be more chaotic and less strategic than is conventionally assumed." (emphasis in original, 2018:579). Despite the advances of these studies, they all acknowledge that further research on the co-constitutive relationship between China and international institutions demands further study (Beeson and Li, 2016:5; Wang and $\mathrm{Hu}, 2017: 832$; Wilson, 2019) 
In summary, although vastly extended, these types of study are still limited. And although researchers have begun to disaggregate the multiplicity of foreign policy actors, beyond a binary of companies and state (Wang and $\mathrm{Hu}, 2017$ ) and beyond the homogenous term 'China' (Hameiri and Jones, 2018), these studies have only explored this China's fragmentation rather than the effects on a fragmented institution. Furthermore, these studies have failed to explore how this fragmentation affects socialisation stories with respect to the different norms that are relevant within particular cases.

This article seeks to interject in one specific area of the debate, and therefore contribute to this emerging body of work. The acceptance of the diversity of Chinese foreign policy actors also necessitates an acceptance of the diversity of locations within existing international institutions that these actors may affect and be affected by. ${ }^{4}$ In seeking to fill this gap in the literature, and responding to the research question, this article makes the argument that there is an aspect of China's engagement with global order (and particularly international institutions) that has been consistently overlooked - international practices. These are the more mundane aspects of engagement perceived by International Relations theories as being largely the administration and process of international affairs, rather than its substantive norm shaping contents. I agree that in large part China's global policies are "platitudes, slogans, catchphrases and generalities, offering 'atmospheric guidance' that other's interpret." (Hameiri and Jones, 2018:581) and that policies emerge through "experimentation and articulation" (Beeson and Li, 2016:3). But, this 'experimentation and articulation' also happens in the day-to-day interpretation within international institutions. As this article demonstrates, practices and bureaucratic engagements can nudge international norms in different directions: as norms are interpreted by practitioners in the process of their day to day activities, these usages and applications can modify patterns of behaviour and adjust understandings of the original norm. (Dworkin, 2004:48; Author, 2018:67). These interactions may not be done because of a mens rea of the Chinese state, nor be seen as officials stepping out of line (Hameiri and Jones, 2018:582). But, through China's engagement with these practices, it is possible that it can gently modify rather than overhaul the existing norms that guide international behaviours.

This paper is situated in the broad international practices approach developed by Adler and Pouliot (2011), Barnett and Finnemore (2004), Neumann (2012), Bueger (2013), and Gadinger (Beuger and Gadinger, 2015), Pouliot and Adler-Nissen (2014), as well as within the considerations of how China engages with international institutions and the works of Ann Kent 
(2009), Alastair Johnston (2003; 2008), Wang Yizhou, and Rosemary Foot and Andrew Walter (2010). The paper makes the argument that through its socialisation into these norms of practice (second order norms), China presents a subtle and pragmatic challenge to norms of principles (first order norms). Or what Kratochwil describes as "the conceptual distinction between social orders based on shared practices and those based on common purposes..." (1984:689)

The article takes the case study of China's engagement with sanctions against North Korea, as a critical case for demonstrating the relevance and importance of the development of this research approach. This case presents a perplexing view of China's socialisation. It has a stated foreign policy objection to the use and some of the purposes of sanctions, but it has continually approved extended sanctions against the regime in Pyongyang. At the same time, it has only partially implemented these sanctions, but it has not been demonstrated to be in substantial breach of them. The focus of this discussion is the degree of socialisation to the processes of sanctions implementation, as a result, it doesn't seek to evaluate the degree of socialisation to the norm of non-proliferation, but rather to expand on the debate of whether China has been socialised to the practices of sanctions implementation, or whether is continues to bargain.

The overall argument is that China has been socialised to some international practices of sanctions (second order norms). China has learnt the processes of the bureaucracy of the UN through which it can champion its own interpretation of international norms shifting its strategy from bargaining to arguing. Regarding sanctions, this means utilising the panel of experts (that monitors implementation and makes proposals to make sanctions more effective) and the sanctions committee (that seeks to act on recommendations from the panel, in addition to its own knowledge and expertise). However, this is not synonymous with China having accepted both the norm of non-proliferation and that appropriate enforcement of that norm is through the use of sanctions. Instead, in reference to these meta-norms and the interstitial linking of them we seen nuance in China's approach that sanctions are acceptable to signal disapproval at the violation of the non-proliferation norm (and hence there is evidence that China is socialised this norm), however, China's engagement with second order norms to frustrate the effectiveness of sanctions in coercing and constraining North Korea indicates that through second order norms China demonstrates that it is not (yet) socialised to the use of sanctions to achieve these goals. In framing this within an English school approach, the practices that China has been socialised to are a part of a pluralist structure of international order rather than demonstrating an explicit acceptance of the solidarist ideas of a world society that focuses on individual rather than state rights (Buzan, 2004). 
This paper proceeds in several parts. First, it outlines the role of international institutions in normative change and consistency. Second, it sets out what international norms are and their different varieties. Third, the paper presents an international practices approach and indicates how this approach enables a unique research agenda for studying China's international engagement. Finally, the paper applies this approach to the case of China's approach to sanctions against North Korea.

\section{What role can institutions play in the renegotiation of international order?}

According to Robert Keohane, institutions can usefully be divided into a "general pattern or categorisation" (Keohane, 1988:383 - emphasis in the original) (for example Hedley Bull's primary institutions such as sovereignty (2002)) and "a particular human-constructed arrangement, formally or informally organised." (Keohane, 1988:383 - emphasis in the original). In this second order of institutions, Keohane refers to organisations and regimes, and it is this second grouping that he focuses his analysis on. Within this study he identifies that within institutions, practices play an essential role in shaping the behaviour and actions of members - whether they are individuals or states. He argues that these practices are "highly institutionalized in the sociological sense of being taken for granted by participants as social facts that are not challenged ..." (Keohane, 1988: 383-4).

In a longer examination of international institutions Keohane developed the definition (later noted by Chris Reus-Smit) that institutions are "persistent sets of rules (formal and informal) that prescribe behavioural roles, constrain activity, and shape expectations." (Keohane, 1989:3; see also Reus-Smit, 2003:556) In behaving within these institutions actors or participants must justify their actions in reference to compliance within these practices, rules or codes of conduct (Keohane, 1988:384; also Cortell and Davis, 1996:452). These two definitions highlight that institutions are maintained through the development of common practices and rules, which are, according to Finnemore, "intersubjective" (1996:22). Intersubjectivity ensures that these rules are distanced from the specific interests of a single state and once rules and practices are formed they are also difficult to change or modify (O’Neill, Balsiger and Ven Deveer, 2004:160; Axelrod, 1986:1097; Reich, 2010:15). Moreover, any change is likely to be "change within the system" (Gilpin, 1982:45; also Ruggie, 1998:42), rather than changing the whole system (Heriter, 2007; Mahoney and Thelen, 2009). Not only will patterns of behaviour be difficult to change, any change will be difficult to be assessed and measured (Kuhn, 1991). 
Institutions are also forums for challenging orders (Author, 2018). Thomas Risse explores this role by indicating that by acting as a forum where states can 'argue' and bargain, institutions are venues in which logics of appropriateness are set (2000: 6). Ole Sending extends this element of 'arguing' by stating that institutions are where abstract norms or ideas are given meaning and a practical expression (Sending, 2002:452). According to Andrew Hurrell, "Institutions may be where state officials are exposed to new norms...; they may act as channels or conduits through which norms are transmitted..." (Hurrell, 2004:42). These three studies indicate the importance of institutions to the implementation and actualisation of new norms. Realising norms, through practices and codifying patterns of behaviour, makes institutionalised norms resistant to change. This happens because institutions formalise obligations into codes of conduct and practices and enshrine them in structures (March and Olsen, 2004:5-7; Loke, 2018:677).

Discussions of reconsideration or modification of norms within the debating chambers of institutions tend to be limited to moments when existing norms no longer 'fit' realities, or when new unforeseen challenges emerge, ${ }^{5}$ or when a new norm is proposed and needs to be reconciled with the existing normative structures and patterns of behaviour (Keohane, 1988:384). In these cases, the changes or contestation of international norms within institutions are limited to normative contests within the great chambers - the UN Security Council, General Assembly. In these locations of normative contestation are open. For example, the debates over sanctions, whereby states lodge a normative as well as practical objection.

However, as noted by Keohane, "were rules of practice to change, so would the fundamental nature of the activity in question." (Keohane, 1988:384) This raises the potential that norms can be modified or changed through changes to practice and patterns of behaviour that have developed around the implementation of a norm. This form of reassessment may - and frequently does - take place in less public venues within international institutions which can also be places for states to 'argue' about the meaning of norms and gently interpret their meaning. The importance of the interpretation of meaning can be found in the mandates of UN peacekeeping operations and in the implementation of UN multilateral sanctions. In these cases the meaning of each authorisation by the UNSC can be modified through 'arguing' in a nonpublic space, or at times in not arguing at all. Although the role of institutions in shaping guiding global norms may be limited, the processes that are seen to be the practices of diplomats form a vital area of opportunity for states to have agency over international norms. 


\section{What is socialisation?}

According to Alexander Wendt, "Social interaction is in part a causal process of mutual adjustment that often has unintended consequences. Socialisation is in part a causal process of learning identities." (2010:82) This suggests that socialisation and social interactions are processes as well as end points of interaction resulting in agreed and common ideas. According to Wendt's critique of Waltz, a problem with neo-realism is that it focuses too heavily on the material outcomes producing patterns of behaviour rather than the development of common ideas (or norms) that guide those behaviours (2010:101-2).

In the constructivist school, it is more common to see repeated social interactions as producing gradual normative changes (Muller, 2004:412). According to Schimmelfennig, socialisation is "the process that is directed towards a state's internalization of the constitutive beliefs and practices institutionalized in its international environment." (2000:111-112; see also Muller, 2004) he goes on to state that socialisation is a process not an outcome. However, in this aspect I disagree with Schimmelfinnig as the practices that he identifies may indeed be a process and hence the outcome is an engagement with a process. But, at its heart this is a disagreement over what he terms 'beliefs and practices' and I breakdown into meaningfully distinct different types of norms.

This disagreement over what socialisation is - a process or an end point - continues in debates in the discipline (see for example: Alderson, 2001; Thies, 2003). In this specific debate, Thies identifies that in Alderson's rendering of the use of socialisation, there confusion between socialisation as being an outcome and a process through which that outcome is achieved. This is a common issue across studies of socialisation as Morin and Gold note, the pathways or mechanisms for state or individual socialisation remain underspecified (2016:1).

These debates and their related confusions are of tantamount importance to this work. First, as Morin and Gold note (2016:2-7), it is essential to understand the level of analysis (whether the state, collections of individuals, or individuals themselves) that is subject to the process or demonstrates the outcome. As noted, above, the day-to-day interactions of policymakers within institutions, according to Keohane, are a central site for the process of the development and emergence of common patterns of behaviour, however, in order to produce an outcome where there is adherence to common ideas (and norms) these interactions need to be replicated (or spilled over) across organisations and bureaucracies. 
The second essential component of this debate is whether - in the international relation context - socialisation is a verb or an noun. Is socialisation a process or an outcome? In relation to the works on China's socialisation to international norms, the majority of scholars adopt the approach of exploring whether China has been socialised to norms of ideas - that is socialisation is an outcome. However, in this piece, the question - what is China socialised to - raises the issue that there are difference types of norms and by distinguishing between different types of norms (see below) China may be adopting patterns of behaviour without acceptance of the meta-idea. Hence, China may be the 'Schrodinger' of Socialisation - both socialised and not socialised. In order to expand this argument further it is first necessary to dwell on different types of norms that connect to the concept of socialisation.

\section{What are international Norms?}

In general, norms are intersubjective facts (Goertz and Diehl, 1992; Axelrod, 1986:1097) that are contextual (Berman, 2001:233; Shannon, 2000:294) and intersubjective (Finnemore, 1996:22) and vary in strength (Goertz and Diehl, 1992; Axelrod, 1986:1097). They provide organising principles for patterns of appropriate behaviour but not the specific details for how that behaviour should be conducted. Hence, the general principles provided by norms are given specific meaning by their formalisation within institutions.

Norms then can vary in type and in the population to which they apply and regulate. Vaughan Lowe (2000:212; also Author, 2018) separates out different types of norms as both primary and interstitial. These different types of norm and the relationship between them create a complicated web of relationships that ensure that any one particular norm is hard to modify or change (Lindner, 2003:916; also Dosi, et al. 1999:24; Hodgson, 2007:110), not least because they also set out patterns of behaviour and prescribe the limits of what actors, states, or members can legitimately do (Smith, 1973:13-14).

It is timely to also identify that within these webs of norms, shifts in the interpretation of both meta-norms and interstitial norms may result in a change in the character of liberalism within the liberal international order (Author, 2018). These shifts may make the liberal international order more pluralist or solidarist. According to these two approaches to liberalism, pluralism seeks to produce accepted but plural types of states that can co-exist within a framework that allows states to "cooperate for their mutual advantage" (Dunne, 1998:11), whereas solidarism seeks to determine acceptable behaviours of states in areas pertaining to individual freedoms and advance a moral not only procedural pattern of state interaction (Dunne, 1998:11). 
Although, this divide is an oversimplification, the division between these two English School approaches remains conceptually useful; particularly as these distinctions enable a separation of types of norms of international society, which is essential for understanding the nature of China's contest here.

At this juncture it is also important to recall that according to Hedley Bull, norms may be both of first order (the guiding ideas) and second order (the functional/instrumental). This is a different distinction from meta and interstitial norms, as both of these previously discussed norms still relate to acceptance of a common guiding idea or objective. It is these norms that are the most common target of discussion in debates in the discipline, for example the discussion of these norms tend to be linked to the level of ideas, for example, ideas about the Responsibility to Protect, intervention or sovereignty, and the relationships between these ideas and actions (see for example, Philpott 2001; Zaum, 2007; Krasner, 2001).

In contrast second order norms can be seem as those related to processes (Kratochwil, 1984). In returning to the route of the term 'norm' and its sociological origins as a pattern of normal behaviour, patterns of behaviour of diplomats and bureaucrats within international institutions, which conduct the practices and comply with the rules that are specified because of the acceptance of norms, could also be considered to be international norms. And given the relationship between ideas-based norms, international institutions, and international practices, these day-to-day norms of institutions may become sites of both normative contestation and state socialisation. Indeed, in 1983 Krasner (cited in Buzan) noted, "Decision-making procedures are prevailing practices for making and implementing collective choice." (Buzan, 2004:163). As a result, the procedures for implementing ideas, norms, and principles, should be considered as locations of normative change. These norms may be considered to be Kratochwil (1984) and Bull's (2002) second order norms. ${ }^{6}$

In considering socialisation as an outcome and a process this distinction is fundamental. In considering second order norms - as functional, behavioural processes - the outcome is in the development, acceptance and engagement with a process. In relation to first order norms, the outcome is an acceptance of the common idea or overarching objective - whether that is a meta- or interstitial norm.

\section{Norms, Socialisation, Order and Practice}

In order to clarify the processes for the relationship between these processes and identify the importance of the actors involved brief summary is useful here. 
In the emergence of second order norms - decision making processes - the vital actors are the bureaucrats and individuals that operate and engage within international institutions (Kratochwil, 1984:689-90) . In order to research and study these interactions an international practice approach is essential. In terms of claims about socialisation the emergence of common processes, regulated and patterned behaviours, developing a common interpretation of the rules is the outcome of this process.

In the realm of first order norms (Bull, 2002:16) - the realm of ideas - the actors involved may be more inclusive, they may result from high level meetings among heads of state, however, as noted by Keohane and others (above) these norms may alter in their interpretation through the process of interaction developed in relation to the process of second order norms. As a result, it is essential that in debates on socialisation, due care is paid to the norms that a state is being claimed to be socialised in relation to, in the case of China's approach to the sanctions against North Korea, this paper makes the argument that China is socialised to the processes that comprise second order norms in relation to sanctions implementation. Through this engagement with this process, China is able to modify the connection between the related and guiding first order norms of non-proliferation and the use of sanctions to ensure nonproliferation. As a result, we can claim that China may accept the norm of non-proliferation, but not the achievement of that norm through the use of sanctions. It registers its nonacceptance of the relationship between these norms through its engagement in the process of sanctions implementation.

\section{Adopting an International Practices Approach - why and how?}

\section{Why look at China and International Practices?}

Adopting an international practice approach is an endeavour that is replete with controversy. Indeed, international practice or the practice turn in International Relations, as a collection of approaches in international relations, may be seen as one of the following: (1) a relatively new endeavour of International Relations - in the terms and approaches set out by Adler and Pouliot (2011) or Bueger and Gadinger (2015); (2) or a central concern since the inception of IR as a discipline - in terms of the study and practice of diplomacy (Ringmar, 2014:2), ${ }^{7}$ or (3) a part of a 'social turn' in IR characterised by the rise in use of ethnographic, constructivist, and poststructuralist approaches since the end of the Cold War (Autessere, 2014). Nonetheless, despite acknowledging the presence and importance of these debates, they in themselves are not the subject of this article; rather this section seeks to draw out the elements commonly associated 
with the 'practice turn' in order to create a conceptual framework through which it is possible to analyse the practice of China in the sanctions committee and the panel of experts.

The benefit of an international practice approach for this discussion is that it enables a number of aspects of China's engagement within international institutions to be brought together and refined. First, it allows for a more systematic and structured account of identifying the roles of the Chinese state, or Chinese individuals, or Chinese companies in assisting in the evasion or implementation of sanctions (Author, 2015). An ability to disaggregate these different elements that currently comprise 'China' in these discussions has the potential to contribute to policy approaches as well as understanding why these policy behaviours occur (Jakobsen and Knox, 2010).

Second, understanding 'where' as well as 'whether' these international practices take place enhances our comprehension of the dynamics of international organisations. In acknowledging that practices may be both, hidden and incremental, there may be a number of locations for normative contestation and change.

Third, this approach enables the consideration of what China might be being socialised to, by opening the box of international norms and practices as they exist within international institutions. In particular, by exploring this aspect of China's engagement within international institutions, an argument emerges that through a process of socialisation to practices, China has learned not only how to develop its own institutional practices in creating its own institutions but also how to fulfil its own policy objectives in a wider range of points of engagement.

\section{International Practices and drivers of evolution of international order}

Bringing together the work of recent practices authors alongside the work of Ruggie and Keohane on international order and its evolution, it is apparent that there are many potential drivers of change. In the broader discussions of order, the focus has been on changing international order through developing new norms or new approaches. For example, in looking at changes to order through new concepts of sovereignty it is possible to identify three major shifts driven by the emergence of new ideas. Krasner defines state sovereignty as the recognition of states by other states (1999:220). Recognition is a social interaction, and as such states can - overtime - adopt different frames of references to determine who they will recognise (Ashley, 1984:273 quoted in Glanville, 2010:4). Since the 1990s, and the end of the Cold War, it is possible to observe a number of shifts in frames of reference which have been 
used to recognise states but also in the states able to provide recognition. One example here is in the recognition of states as independent entities following calls for independence. Although in the evolution of sovereignty discourses focus on changing ideas leading to changes to practices of recognition (for example Philpott, 2001), in the work of Zaum (2007) it is possible to recognise that some states achieve functional sovereignty, through their provision of the functions of a sovereign states, even though they lack formal recognition by major powers: Kosovo and Taiwan could be seen as examples here. Similarly, states may gain formal recognition through their practices within order, for example, Taiwan's inclusion in the World Trade Organisation (WTO) and the Asia-Pacific Economic Cooperation (APEC) forum. In considering this practice approach in relation to sovereignty, it is clear that as a result of changes to how states behave within international order, the constitution of international order can change: the composition of states recognised as legitimate entities to participate and contribute changes. However, it is less clear how day-to-day practices could shape international order.

Sanctions are a very useful example. They have been discussed in the literature as a means to seek to change specific behaviours that are deemed inappropriate and the use of sanctions has crossed the boundaries between pluralist and solidarist norms. They are effective through their ability to either coerce, signal or constrain the actions of a state (Biersteker et al, 2016:11-13). In seeking to change state behaviours such as the development of weapons of mass destruction, constraining access to specific goods may be sufficient. However, in seeking changes to governance and to obtain greater protection to populations, sanctions may be more successful if they coerce and signal inappropriate behaviour.

Indeed, in looking at the diversity of levels of sanctions implementation across the different elements of sanctions (coercion and constraint), the different types of practices China uses shapes the nature in which sanctions operate and therefore what process and types of behavioural change they can produce. As China's focus on implementation is on constraining access to specific goods, this limits the types of behaviour that can be punished or changed through their application (Author, 2018b). In consequence, this demonstrates China's socialisation to norms of procedure connected to sanctions, but not its acceptance of the norms that sanctions seek to enact.

International Practices: socialisation or bargaining? 
An issue here is whether China's behaviours are, therefore, indicative of a practice of bargaining or a process of socialisation. It is important to distinguish and identify the relationship between bargaining, arguing, and socialisation. The argument in this section is that bargaining and arguing that are demonstrably effective and specific to a particular forum comprise evidence that socialisation to this process of interaction has taken place - the state actors involved have learned the decision-making behaviours that can shape the organisations understanding and implementation of meta- or interstitial norms. To support this line of argument, and thereby demonstrate that China's behaviour is not just a demonstration of bargaining but indicative of China's socialisation. This section outlines the literature on arguing, bargaining and socialisation and uses this literature to present a schema for using the methods of international practices to develop and argument of socialisation.

According to Muller, there is a clear distinction between arguing and bargaining:

"Arguing contains claims of factual truth or normative validity and intends to convince. Bargaining contains promises and threats and intends to change behaviour." (2004:397)

In each of these exchanges the sender (arguer or bargainer) deploys these as tools to affect a response from a target. In contrast, in socialisation research the subject is the affected party, if a party has been subject to a process of socialisation they may use bargaining or arguing, but the focus is on whether their norms, preferences or actions have been modified or altered over a period of interaction with other entities that have a different approach. In the basic understanding of bargaining and arguing interactions, the focus is on a single or series of interactions over a particular issue or instance. They do not fundamental seek to adjust the receivers' frame of reference. Whereas in socialisation the aim of interaction (which may include both bargaining and arguing) is to change the frame of mind of the receiver.

Moving beyond the general view this literature has moved towards the interplay of bargaining and arguing and its relationship to socialisation. It is considered in the context of a perpetual prisoner's dilemma (Fearon, 1998:271-276) where repeated interactions can shape expectations of the reactions of the other. Or in considering the importance of the context of the bargaining process (open/closed door) in affecting the engagement (Stasavage, 2004). However, these works, and the larger literature on bargaining, fails to outline the relationship between the process of bargaining and the potential outcome of socialisation. 
The use of international practices enables researchers to more clearly identify if a sender has changed their strategy of engagement with others but also to understand if this is because their frame of reference has altered - their perception of the logic of appropriateness has been changed - or if they have adopted a different strategy in order to pursue the same policy aims. In the case of China's engagement with sanctions in respect to North Korea this gives a clear outline of the potential indicators of these different actions.

In separating out the different expected actions from arguing, bargaining and socialisation enables us to understand more readily the degree to which China has been shaped, or is shaping, international order within institutions. The outline of behaviours below, will then be used in the conclusion to evaluate whether China's type of behaviour or approach has altered, or whether it has been socialised, and if it has been socialised, whether this is to a different logic of appropriateness, or a more effective form of behaviour.

Actions of arguing:

- Use of facts or the truth in presenting a case.

- Seeking to convince other actors of the 'rightness' of their approach.

- Engagement with other actors to present their argument, within a frame of appropriate action.

Actions of bargaining:

- Use of threats or promises to change the policy preferences of other actors.

- Lack of discussion of 'right' or normative goods.

- Seeking to activate a logic of consequences in the behaviour of others using threats.

Evidence of socialisation to the second order process norms of sanctions implementation

- Change in the use of bargaining or arguing over the same case.

- Policy or behavioural shift over a period of interaction.

- Continuous interaction of the same individuals on the same topic over a significant time period.

\section{Research Methods and approach}

By adopting a relatively concordant understanding of practices, defined as competent patterned performances that apply some background knowledge and are demonstrated in both discourse and material actions within a social setting, it is possible to understand sanctions design as an 
on-going process rather than a singular instance (Adler and Pouliot, 2011b:6-8). The 'practice' of sanctions implementation and specification would need to contain four key elements: ${ }^{8}$

(1) A social community which has a clearly demarcated membership that consistently interacts (either through common endeavour, or overlapping activities, or through narratives that have common explanations of common activities);

(2) Collective shared knowledge specific to the operation of a practice;

(3) A pattern of associated activities that are 'performed' by the community (individually and collectively); and

(4) Use or the creation of material objects.

This understanding of international practices presents a list of things that need to be looked for in identifying whether China has been socialised to a particular practice. However, this framework also presents a problem. It has long been recognised that there are difficulties in researching institutions and the inappropriateness of a number of methodologies has been noted in the international practices literatures. Indeed, the research area arose because of frustrations from the academic/diplomatic communities that the real world of diplomacy was not being accurately captured by IR texts (see for example, Adler and Pouliot, 2011; Neumann, 2012; Navari, 2010; Barnett and Finnemore, 2004). The international practice approach was championed by a small group of scholars working on international institutions. The methods of choice for the study of international practices are ethnographic participant observation (Bueger, 2014) coupled with elite interviewing (Adler-Nissen and Pouliot, 2014:897; Pouliot and Cornut, 2015:308; Pouliot, 2013:48-49), within a process tracing approach. However, despite this new theoretical gold standard, it has proved almost impossible to achieve. Limitations in terms of resources, time and access all combine to make it nearly impossible to undertake an ethnographic study of an international institution. Despite these problems, there are a number of studies that would conform to this gold standard. However, this perspective has only been applied to western institutions. Moreover, the connection to area studies approaches haven't been recognised.

The research in this paper was undertaken over several years. It has included interviews with elites in the United Nations headquarters (UNHQ) in New York who are able to consider China's behaviour within the UN. It has also benefited from two periods of participant observation at the UN in New York in August 2016 and October-November 2017. It has also involved a detailed exploration of the documents available through the UN and also the commentaries of other observers present in the UNHQ. Throughout the remainder of the text 
the interviews have been anonymously rendered in compliance with research ethics and approvals from the subjects. Where appropriate the participant observation information has been identified in the footnotes and in each instance of both interview and observation use, triangulating open source data has also been sought. As a result, the attempt has been to identify verifiable sources for subsequent researchers to follow but also maintain the high standard of research ethics.

Given the attempt to provide open-source data, and although, documents are not as highly regarded as evidence in practice, in the area of political geography, an argument has emerged that documents are both the material productions of practice and constitutive of the practice (Weisser, 2014:55). As demonstrated in the discussion of the case below, and highlighted by an interviewee, the construction of the document (e.g. the panel of experts annual report) was a part of the international practice, in particular the decisions as to where information was relayed (main body, footnotes, appendices, or redacted) played a crucial role in assembling the report, and was based in part on which sections of the report were less likely to be read. The exploration of the final document, in combination with elite interviews, presents a greater insight into the development of the practice of the panel.

\section{Case Study: China and Sanctions against the DPRK}

In its 2005 White Paper detailing UN reform, China has highlighted its policy that sanctions should only be used in a case of last resort and when imposed by the Security Council they should be complied with.

"China has always maintained that sanctions should be applied with prudence on the precondition that all peaceful means have been exhausted. Once the Security Council decides to impose sanctions, all countries are obliged to comply strictly” (PRC Position Paper, 2005:Sec6 - emphasis added).

Ostensibly this indicates China's acceptance of the use of sanctions, and that - within appropriate safeguards - they can be used to signal, constrain, or coerce a target state to change its behaviours (Biersteker, Tourinho, Ekhart, 2016:11-13). In line with this policy, China has approved sanctions against North Korea in the Security Council since October $2006^{9}$ and its statements to the Council has indicated that this is a measure of last resort until it is possible to return to dialogue through the Six-Party Talks (for example, UN Document, S/PV.8039; UN Document, S/PV.8042). 
However, the second element of this policy - strict compliance - is where China's position is contested. Since the advent of the sanctions in 2006, China has been consistently accused of being in breach of the sanctions approved. ${ }^{10}$ Indeed, Chinese academics that appear in Wikileaks (2007) reports have also stated that China does not and will not apply the sanctions in full. Moreover, Chinese statements in the UN Security Council have also demonstrated that China is uncomfortable with inspecting cargo that travels to the DPRK.

"China does not approve of the practice of inspecting cargo to and from the Democratic People's Republic of Korea. We therefore have reservations about the relevant provisions of the resolutions" (UN Document S/PV.5551:4).

"I wish to stress that the issue of cargo inspection is complex and sensitive. Countries need to act prudently and in strict accordance with domestic and international law and on the condition of reasonable grounds and sufficient evidence" (UN Document, S/PV.6141:3).

Despite China's own statements, and the frequent claims by other actors that it has breached sanctions, there are also reports that China has imposed sanctions in excess of the requirements of the UN sanctions approved (Berger et al, 2018:5; also Dill, 2018).

As a result, this case study presents a confusing picture of China's normative preferences regarding sanctions and its international practices. In particular, it demonstrates that arguments in favour of or against China's international socialisation could use this case to support their respective claims. This presents the opportunity to explore what particular types of practices within the broader international sanctions regime and the institution of the UN specifically into which China has been socialised.

China's behaviour prior to socialisation to arguing and bargaining norms

China's engagement with international institutions has undergone a series of developments and a gradual process of learning. As a result, it would be misleading and artificial to suggest that there was a clear moment or point around which China's behaviour pivoted. However, after the provocation by Robert Zollick in 2005, that called on China to become a responsible stakeholder, academics have increasingly considered whether the nature and contribution of China has changed. In the case of sanctions against North Korea this date creates a challenge, as the most recent round of sanctions were only initiated after the nuclear test in 2006. 
However, this is an overly simplistic view of China's engagement on this issue. In the 1990s and as late as 2002 (before North Korea withdrew from the non-proliferation treaty in 2003), the UN Security Council discussed how to manage an increasingly assertive North Korea. Whilst, China was a key driver behind the six-party talks and therefore in shaping the location and content of the program of management, China (and Russia) reportedly objected to the prospect of UN sanctions so greatly that it was not placed on the table for discussion at the UN (Rennack, 2006: 3). At this point, not only was China not on board with sanctions as a coercive tool, it also objected to them signalling displeasure at North Korea's subsequent withdrawal from the NPT. At this stage, we see that China doesn't argue or bargain within international institutions but rather prevents options being placed on the table.

In 2006, after North Korea has tested a nuclear weapon, China not only allows for the discussion of sanctions but also votes in favour of their imposition. This engagement is therefore the starting moment of China's arguing and bargaining process. However, it is noted (below) that at this stage China's acceptance of sanctions is not fully backed up with implementation, and indeed the more sophisticated arguments become apparent after the establishment of the Panel of Experts, in 2009. It is the responsibly of this panel to investigate sanctions violations and report to the committee and Council as to how sanctions can be designed to be more effective. As a consequence of the imposition of sanctions and the creation of the committee (2006) and the panel (2009) China's actions in relation to sanctions against the DPRK need to be argued, justified and defended in a greater number of fora throughout the UN.

In the next section, this paper outlines how China has engaged with these processes and fora and how far it has moved from a simple objection, to debate sanctions (in 2002) and then towards a nuanced and sophisticated engagement with the process of implementation.

\section{Practices of Sanctions Implementation}

Sanctions undergo a number of processes towards specification and implementation following a UN Security Council authorisation. These processes include further specification of the terms of the sanctions by the relevant sanctions committee. As soon as a Panel of Experts (PoE) is appointed, it has the responsibility to conduct investigations into compliance with the approved sanctions, and to make recommendations on lists of products and people of entities that could make those sanctions more effective. 
Although these roles appear to be functional, because of the investigation and recommendation aspects of their work, these too can be seen to have political meanings - especially in their roles regarding the recommendations of individuals and entities that should be added to sanctions, their role in determining what 'evidence' is regarding sanctions violations, and their function in reporting information to the sanctions committee. As a result of these activities, panels can be seen as having a common or shared endeavour to apply a shared specific knowledge. Taken together, they can be considered to be international practices. Yet, by separating out these stages and identifying the mechanisms that comprise this practice, it provides an even more useful and systematised approach to looking at the processes that take place after the authorisation and to identifying all of the potential points of engagement. It also enables 'compliance and acceptance' to be seen as a process rather than a single event; and allows for a more accurate understanding of the Chinese actors involved.

For the purposes of the analysis that follows, it is apparent that across the sanctions committee, PoE, and implementation activities on the ground, there are two main elements that constitute international practices which are open to states' or implementers' interpretations within this community: those within the UN (panel of experts and the sanctions committee) and outside the UN when implementation on the ground takes place. Within these two elements there are a range of activities that states may perform that have a potential to influence the efficacy of the sanctions regime.

As this paper is primarily interested in China's actions within the UN, the focus of this paper will be on the Sanctions Committee on North Korea (the 1718 Sanctions Committee) and the Panel of Experts. These two groups meet the requirements of being an international community, in that they have the requisite knowledge needed to participate in the international practices of sanctions committees and panels, they are a finite group of people, and they produce material outcomes (in the form of recommendations and reports). The practice of being on a panel or committee requires the participants not only to cooperate but also to have the specific knowledge in order to carry out the practice.

To explore China's compliance with the international practice of being on the 1718 Committee and Panel of Experts, this paper explores one particularly problematic element that is consistent in all of the sanctions approved since 2006 - the process of specifying people and entities that are to be sanctioned.

\section{Shifting behaviours regarding sanctions on North Korea}


In considering whether China has been socialised or merely used bargaining and arguing as tools in its interactions regarding sanctions against North Korea, it is essential to consider whether China's approaches have changed, and if they have in what way they have changed.

In a document dating back to June 2009, Shen Dingli was reported to have claimed that "China has long been violating UN Resolution 1718 by exporting Luxury goods to North Korea." ${ }^{11}$ In this report, two Chinese academics, Liu Ming of the Shanghai Academy of Social Sciences and Shen Dingli, had both made comments claiming that China has and would continue to violate sanctions against North Korea, particularly over the clause regarding luxury goods contained in resolution 1718. This section outlines that China's approach to demonstrating formal compliance with this aspect of sanctions goes beyond behaviours associated with sanctions busting (Early, 2015) and therefore a rejection of the sanctions. As detailed below, China has seemingly scrupulously implemented a legalistic and limited interpretation of the ban and provided evidence of its compliance. It suggests that China has neither bargained nor argued about the contents of the sanctions before implementation but has instead provided an argument for its full implementation. This indicates a change in China's approach between 2006 and 2016 and indicated a change in its frame of reference for when and how it is most effective to present this argument. It is also clear that the subject of the argument has shifted from the appropriateness of sanctions to the regime and approach of procedures for assessing compliance. It therefore demonstrates a shift from contesting a norm to contesting a rules based practice.

The first element to note concerning the implementation of the ban on luxury goods is that it is, according to one commentator, the only 'tough' economic sanction that Beijing allowed to remain in resolution $1718(2006) .{ }^{12}$ This appearance of co-ordination and unanimity over sanctions is little more than a myth. The stated intention of banning luxury goods was to directly affect the ability of the regime to maintain internal control. Western states hoped that by preventing the distribution of gifts to the cadre of leaders in Pyongyang it would weaken the regime without negatively affecting the situation of an already struggling population. ${ }^{13}$ However, the approaches of China and Russia were slightly different. Russia's chief concern was whether this prohibition would affect their ability to supply their embassy in Pyongyang with sufficient supplies of Vodka, while the Chinese concerns seemed to be on accidentally prompting a regime collapse. There are different standards invoked in applying the sanctions on 'luxury goods' that indicated the different policies being sought by the states involved. 
In responding to the diversity of interpretation and objectives in banning luxury goods, it is noteworthy that UN resolutions 2087(2013), 2094(2013), 2270(2016) and 2321(2016) specified a list of assets to be frozen and travel bans to be enforced. In contrast resolutions 1718 (2006) and 1874 (2009) left the specification of travel bans and assets to be determined by the Committee. ${ }^{14}$ The committee, acting in consensus, then also approved the following definition of luxury goods in an attempt to close this loophole in the sanctions regime: "Luxury goods are considered to be superior to the comparable substitutes in terms of design, durability or performance." 15

This definition means that the identification of luxury goods remains subjective and controversial. Significantly it places the determination of a 'luxury' in a domestic realm of each implementing state rather than within international institutions. In the case of North Korea the debate and discussion of what counts as luxury goods is an area of considerable contestation, ${ }^{16}$ and the location of interpretation has a significant effect on the efficacy of the sanctions. Hence, the tools of the panel, committee, and standards of evidence (discussed later) all present a complex pattern of divergences between co-sanctions that occur after authorisation, but are institutionalised in order to continuously achieve ineffective sanctions, under the appearance of formal compliance.

\section{Specification of Entities and People}

Making sanctions work rests on whom and what is to be sanctioned and the relation between sanctioned items and the people with the desired behavioural change within the state. The ability to shape who and what is to be sanctioned provides some indication of the commitment of a state to those sanctions achieving their designated aims. In order to have influence on this process, a state or actor needs to be a member of the panel or sanctions committee, have the requisite knowledge and the ability to act - in order to achieve their own foreign policy objectives, they also need to be able to use this knowledge to produce a competent international practice. The threshold for participating in this situation is high, as when discussions take place as to the specification of the sanctions, it is of vital significance that an immense knowledge and understanding of the state concerned is brought to bear on the subject as well as the process of designation.

In this case of North Korea, Haggard and Noland have claimed that "China has been utterly unwilling to use its vast commercial and aid leverage to force a reckoning" (2012:259). This section explores whether this claim remains valid and whether there is evidence within the 
specification of the sanctions that verifies it. In concluding this section demonstrates that this claim remains valid when this reckoning relates to the coercive aspects of sanctions, but it is less valid when related to sanctions signalling.

The creation of the PoE pursuant to resolution 1874 (2009) contributes information regarding whom and what should be sanctioned. ${ }^{17}$ China, having a close relationship to the DPRK, has the opportunity to intensify the ability of the PoE to fulfil its requirements and is in a position to be particularly useful. In this sense, if China were fully socialised into the practice of international sanctions and in harmony with the intention to encourage North Korea to change its behaviour as a consequence of the imposition of sanctions, it would be expected that China would bring its specific knowledge to bear through providing timely and detailed evidence to the panel of experts and by approving additional names and entities in the committee. However, it is frequently noted in Panel reports that evidence and information from China has been both less frequent than other regional powers' and less detailed than would be helpful for the Panel of Experts. ${ }^{18}$ For example, the 2013 report noted that requests to China for further information on some cargo and aircraft have not yet received a response (UN Document S/2013/337:34). ${ }^{19}$ Similarly, in the 2017 report it is noted that requests to China for information had (at the time of publication) so far received no response (UN Document S/2017/150:42 and 49).

Therefore, it appears that China could have brought knowledge to bear in making sanctions more effective but it has failed to do so. This suggests that it is plausible that China has been socialised to the imperative of sanctions in the light of North Korea's behaviour that violates the international non-proliferation norm, insofar as it can authorise sanctions in the UN Security Council but through bureaucratic processes it can ensure that they are less effective than they should have been.

Even after the Panel has managed to acquire enough evidence from a range of sources in order to make recommendations to the committee to add names and entities to the sanctions regime, Beijing has in the past "whittled down the list of North Korean companies to be sanctioned from the 40 proposed by the US, EU and others, to three." (Cossa and Glosserman, 2012) Thus, China can be seen to use the tools of the practice that specifies the sanctions as a means of muting their effectiveness. On the one hand this appears to be a form of bargaining, where China rejects or contests the policy preferences and fails to engage with normative preferences, however, the structure of China's rejection is to adopt a frame of reference common to all members but within these frame reject specific entities. As a result, the structure of China's 
engagement appears to be moving towards arguing and away from bargaining and therefore towards being socialised into the bureaucratic mechanisms.

In a similar issue around specification, the issue of luxury goods, China is also demonstrably adept at utilising the tools of the UN processes in order to ensure that it can 'justify its abrogation from sanctions expectations with reference to the accepted rules and processes.' In doing this it has clearly shifted to using the tool of arguing.

In the UN Security Council resolution 1718 of October 2006 luxury goods were banned. The intention was to deprive the elites in North Korea of the preferred lifestyle and in doing so coerce them to move away from the development of nuclear technologies and missiles and return to the Six-Party Talks. ${ }^{20}$ In 2006 this was the only hard sanction that Beijing would approve (Xu and Bajoria, 2014), yet after its approval it has developed its own pattern of behaviour to interpret the resolution.

However, luxury goods as a term in the sanctions was insufficiently specific to choke off the flow of these goods, especially as it was left up to nation states to determine what counted as a luxury. Over the course of the next decade, the panel and the UN in general sought to close this loophole by providing more detail as to what a luxury good was. The UN took the step of writing a note of clarification to assist states in the implementation of this sanction. ${ }^{21}$ It provided the definition:

"Luxury goods are considered to be superior to the comparable substitutes in terms of design, durability or performance. Luxury goods are often associated with certain brands whose names are preferred by those consumers with strong purchasing power. ${ }^{22}$

Similar to the practices with regard to aid transparency and consistency, states and other international entities published lists of goods counted as being a part of the sanctions to aid businesses trading with the DPRK not to break the sanctions. However, China has consistently been identified as exporting goods that in other states would have been counted as being luxuries.

A case is instructive here. In the Panel of Experts reports of 2012 and 2013, there is a very clear note that China doesn't try, to comparable extents, to define and implement the ban against the shipment of luxury goods. ${ }^{23}$ That is, the intentions behind banning luxury goods may be either to choke off a supply of goods intended for the development of nuclear capacities, or to apply 
pressure to the elites in North Korea to compel compliance and end nuclear and missile testing (Author, 2017). In response to reports from Japan, the panel of experts also investigated shipments to North Korea including cars and computers. On requesting information about these goods and shipments from China, the panel published the following information: "Chinese customs officials told the Panel that most of the above-mentioned goods were not considered luxury goods by China." (UN Document S/2012/422:para.80) Yet, within the context of the development of the DPRK's nuclear capabilities, the shipment of vehicles and computers can greatly contribute to these technologies.

Similar cases can be seen in later reports that included the shipment of jet airplanes photographed at the Pyongyang air show that had been bought from Italy and New Zealand (where they are considered luxuries) passed through an intermediary in China and arrived in North Korea. But, again China didn't consider these to be 'luxury goods' (UN Document $\mathrm{S} / 2017 / 150: 48$, para.127). Similarly, in the 2016 report, an investigation into ski equipment demonstrated that it had been bought and shipped through China where it was not considered a luxury but in Canada it was considered as such (UN Document S/2015/131:42, para99). Although it is possible to claim that China is not deliberately acting in this way, academics in China, Liu Ming and Shen Dingli, are reported in a WikiLeaks document as claiming that China would continue to violate sanctions against North Korea, particularly with respect to luxury goods (Wikileaks, 2009a). According to studies of China's implementation of these sanctions, it appears that China has tightened sanctions that directly constrain North Korea's access to goods to continue its nuclear program, however, it has continued to liberally interpret the elements of sanctions that are aimed at coercing the North Korean leaders to change their international behaviour that is sanctions related to luxury goods (Author, 2018).

Overall, this example demonstrates some key aspects of China's use of an international practice. First, it has acted to ensure that it is within the necessary international community of practitioners (in both the Sanctions Committee and the Panel of Experts) in order to be able to utilise this tool (Wikileaks, 2009b). Second, China has the high level of specific knowledge in order to be able to make sure of the different competencies of the three elements to the sanctions regime (Council, Committee and Panel). Third, China is assistive in producing the material documents that arise from this practice and has in the past ensured that this material artefact is not publicly distributed. ${ }^{24}$ China has, therefore, demonstrated that it is a competent practitioner in the practice of the sanctions regime against North Korea. Through its practice in this case, China has also demonstrated the limits of its acceptance of the general norm of sanctions, and 
exactly what it means when it says they need to be 'strictly' complied with. However, it has also demonstrated a shift in practice from bargaining (and rejection of inspections) and a rejection of a logic of appropriateness towards arguing (justifying its behaviour in relation to a logic of appropriateness) regarding their compliance with this logic. This suggests China has become socialised to a process of arguing in this aspect rather than bargaining.

\section{Standards of Evidence}

How a country defines what counts as 'credible information' provides some evidence as to how committed a state is to the implementation of the intention of the sanctions - or indeed what that state believes to be the purpose of the sanctions. Understanding the standards of evidence and whether the state argues or bargains over them also reveals whether a state has been socialised to the underlying norm or just the process of interaction.

A significant and distinctive element of China (and Russian) approaches towards engagement with the UN is their understanding of what counts as credible evidence. ${ }^{25} \mathrm{In}$ particular, they seek to ensure that evidence used in the UN comes from member states rather than NGOs, media, or individuals. ${ }^{26}$ In 2009, when China provided comments on a sanctions resolution drafted by the US (that was accepted as resolution 1874), it noted that any inclusions of names on the sanctions list should result from evidence of "verifiable acts". ${ }^{27}$ The tool at work here is evident, that by ensuring a standard of evidence that must be upheld, in either adding names to the sanctions list or in the investigations of the panel of experts, ${ }^{28}$ it is possible to then reject significant evidence provided regarding sanctions violations.

As noted in resolutions 1718 and 1894, China has made it clear that it is against the inspections of cargos bound for the DPRK. Also evident in the resolutions (including 2094) it is highlighted that there is a need for "credible information that provides reasonable grounds to believe the cargo contains items the supply, sale, transfer, or export of which is prohibited by resolutions ..."29 there is scope for interpretation as to what for each country counts as "credible information' ${ }^{30}$

In looking at the definition of arguing from Muller, here the issue is what counts as 'the truth' in order for it to be counted as arguing, it is clear that China as adjusted from just not engaging with the structing of the process towards shaping the ground-rules on which the actors engage. This is not evidence of merely a bargaining or arguing approach but an active shaping of what these behaviours are comprised of. 
Taking this example, we can draw the conclusion that China is committed to fulfilling the legal requirement of the sanctions. It required and provided an end-user certificate, but it did not ensure that there was no scope for that cargo to contribute in any way to the nuclear capabilities of North Korea. Thus, China is committed to the letter of the resolution and can be shown to be upholding its international commitments, however, there is scope for doubt whether this commitment is fully to the stated purpose of frustrating progress towards increased nuclear capacity. By acting within the practice community China is placed in a key position to be able to inform the wording of the sanctions regime, hence the two aspects of refining and assessing the sanctions regime are operating in relation to one another and demonstrate the knowledge and competence of China as an actor.

This approach to evidence is therefore a crucial final problem, i.e. the issue in determining sanctions' violations by the PoE. The PoE receives various forms of evidence, yet evidence from NGOs may not have the approval of all members of the committee. A further element of China's practice is to manage what can become relevant 'knowledge' within the practice community. Thus, in a situation where accurate evidence is hard to come by, further restrictions on the kinds of evidence that can be used, can be an important political practice affecting the contents of the material artefacts produced. This means that the panel tries to find a state sponsor for evidence that originated via another source. However, this is not always possible and may not be the result of solid evidence.

Evidence is also important in the initiation of whether to search vessels or cargos travelling to or from the DPRK. As noted in China's statements on resolutions $1718^{31}$ and $1874^{32}$ China has made it clear that there is a need for credible evidence to be shown before a cargo is inspected. However, what counts as 'credible evidence' for China is different to what is credible for Western states (and Japan) and this may have an effect not only on stopping some cargoes but also in the amount of reported materials the PoE has to deal with in order to continually refine and improve the effectiveness of sanctions.

Moreover, Noland argues that the 'credible information clause' in the sanctions regime is highly significant for implementation, as "it allows a government to say that it lacks the information needed to assess the situation or apply the sanctions." ${ }^{33}$ China has been intransigent over specifying what can be sanctioned, but also what modes of transport it will inspect. This pattern of behaviour from China indicates greater evidence of bargaining rather 
than of socialisation over the issue of evidence, as there is not a noticeable shift in China's position.

\section{Conclusion}

What norms and international practices is China being socialised into in the area of sanctions against North Korea? This paper has argued that China has demonstrated that it has been socialised to the practices of the imposition and implementation of sanctions against North Korea. In this it has shifted from outright rejection of the process or utility towards the engagement with and shaping of what sanctions are, what they can achieve, and how they can be adjusted. Furthermore, China has demonstrated its ability to justify its abrogation from the expectations of the international community in imposing sanctions, with reference back to the terms of the agreement. China has competently used practices to achieve modifications to the 'idea of sanctions' within the limited confines of the institution. In doing so, over the process of the decade of sanctions China has also ensured that its interpretations 'fold back into practice'. In some cases this has led to a tightening of the sanctions, for example in China's tightening of controls of sanctioned North Korean companies operating in China, as indicated in the investigation by Berger et al (2018), and the use of alternative bureaucratic practices (such as adding of appendices to resolutions rather than leaving listing to the committee), but it has also set up mechanisms through which violations of the intended purposes of the sanctions cannot be viewed as (utter) non-compliance with the sanctions.

Hence, China has been socialised into a liberal practice, and through this practice can argue that it is compliant with liberal norms. This depends on a both a presentation of the truth and a dispute as to what evidence is appropriate rather than the use of threats: evidence of arguing rather than bargaining. However, at the baseline, China has consistently bargained with other international actors over what counts as evidence. As a result, there is evidence that China has been socialised to a practice of arguing in some aspects of engagement with sanctions, but also continues to bargain over fundamentals of engagement such as standards of evidence.

Through this process of interaction China incrementally nudges what that norm means in relation to international order. The nature of China's practice highlights its preferences for sanctions only to be used to constrain access to certain goods without seeking a change to the type of governance in a state or to signal problematic human rights records. Its implementation practice, China then resets the boundaries of what types of behaviour can be admonished with the application of sanctions, and thereby changes the behaviours deemed inappropriate for 
other states to comment on and intervene in. Crucially, this is a behaviour that China has adopted and adjusted to over time, in the first interactions in the UNSC or the sanctions committee, China did not seek to engage but rather uphold a line. In these interactions China can be seen to have been socialised to 'argue'.

In addition to this argument, this article sought to demonstrate the importance of separating out the levels and activities that states may be socialised into within international institutions. It sought to demonstrate and argue that it is worthwhile, although difficult, to seek to investigate what China may be socialised into within international institutions, as the layers and processes that comprise the everyday' practices in these institutions can have profound effects on the realisation of international norms. This article, then, is not the end of the story about China's reinterpretation of international order, but rather a place to start looking, with new methods, approaches, and places for where normative contestation may be located.

\footnotetext{
${ }^{1}$ This also links to the argument made by John Ikenberry, that international order will be difficult to change because it has been institutionalised, see, (Ikenberry, 2001, 2009)

2 This claim is also made by Amitav Acharya (2018:2) there are a number of books concerned with institutional change, see for example, Heritier, 2007; Mahoney and Thelen, 2009.

${ }^{3}$ Suzanne Xiao Yang has explored the Chinese approach towards sanctions against Iraq, (Yang, 2013:185).

${ }^{4}$ This is related to internal institutional balancing within the literature. (Yuan, 2018:113)

${ }^{5}$ This is referred to as new issues in Jones, 2018 Chapter four.

${ }^{6}$ I thank Jacinta O'Hagan for leading me to this literature on first order and second order norms.

${ }^{7}$ Note also that Keohane (1988, 1989), Gilpin (1982) and Ruggie (1988) in the 1980s and 1990s all indicated the importance of practices in their discussions on international institutions.

${ }^{8}$ These indicators are a synthesis of the works of: Adler and Pouliot, 2011b:14-17; Bueger, 2015; Bueger and Gadinger, 2015:453; Hopf, 2010; Adler-Nissen and Pouliot, 2014.

${ }^{9}$ UN Document, S/Res/1718, October 2006; UN Document S/Res/1874, May 2009; UN Document S/Res/2087, February 2013; UN Document S/Res/2094, March 2013; UN Document S/Res/2270, March 2016; UN Document S/Res/2321, September 2016; UN Document UN Document S/Res/2356, June 2017; UN Document S/Res/2371, August 2017; UN Document S/Res/2375, September 2017; UN Document S/Res/2397, December 2017.
}

10 “...particularly China, displayed reluctance to fully embrace and implement sanctions.” Noland, 2009:9. Also, Hibbs, 2012.

${ }^{11}$ Wikileaks, 2009. 'China unlikely to fully implement sanctions on North Korea: A view from Shanghai' original sent on 12 June 2009, published on Wikileaks

https://wikileaks.org/plusd/cables/09SHANGHAI257 a.html accessed on 21 November 2017.

${ }^{12} \mathrm{Xu}$, Beina and Bajoria, Jayshree, 2014, 'China North Korea Relationship', updated August 22 2014, p.3

${ }^{13}$ Interview with a former member of the panel of experts, November 2017. 
${ }^{14}$ UN Document S/Res1718 (2006) and UN Document S/Res1874 stated that designation of persons or assets should be determined by the committee or the Council, but the resolution left this to the committee.

${ }^{15}$ UNSC Committee established, "Implementation Assistance Notice No. 3: Guidelines for the implementation of measures regarding "Luxury Goods" under UNSC resolutions 1718 (2006), 1874 (2009), 2087 (2013) and 2094 (2013)" published $5^{\text {th }}$ December 2011, updated 25 ${ }^{\text {th }}$ June 2013

${ }^{16}$ As noted in PoE reports the divergent definitions of luxury goods prevent sanctions being more effective. UN Documents: S/2010/571 pp.28-9, p34 (para.85); S/2012/422 pp.19-21, 31-35, S/2013/337 pp.41-41

17 Details of the PoE and their reports are available at: http://www.un.org/sc/committees/1718/panelofexperts.shtml (accessed 31st July 2013).

${ }^{18}$ China has (of 2014) reported to the PoE which was noted by one interviewee as significant step for China. Nonetheless, the distance between what gets reported and what information it is necessary has proved a difficult issue for the PoE, as has confusion over report expectations, e.g. (UN Document S/2013/337:35)

${ }^{19}$ (the United Arab Emirates has also not responded to requests).

${ }^{20}$ Interview with a former member of the panel of experts, November 2017.

${ }^{21}$ UNSC Committee established, "Implementation Assistance Notice No. 3: Guidelines for the implementation of measures regarding "Luxury Goods" under UNSC resolutions 1718 (2006), 1874 (2009), 2087 (2013) and 2094 (2013)" published $5^{\text {th }}$ December 2011, updated 25 ${ }^{\text {th }}$ June 2013.

22 UNSC Committee established, "Implementation Assistance Notice No. 3: Guidelines for the implementation of measures regarding "Luxury Goods" under UNSC resolutions 1718 (2006), 1874 (2009), 2087 (2013) and 2094 (2013)" published $5^{\text {th }}$ December 2011, updated 25 $5^{\text {th }}$ June 2013

${ }^{23}$ UN Document S/2012/422 and UN Document S/2013/337; see also "Clearly, China holds the key to implementing sanctions on the DPRK ... It could arguably devote more resources to detecting and stopping North Korean violations" (Wikileaks, 2010)

${ }^{24}$ As noted in the 2012 report of the panel it is noted that China prevented the publication of the report from 2011. UN Document S/2012.422: fn12.

${ }^{25}$ Author Participation, UN Headquarters, October to November 2017, especially, meeting, $28^{\text {th }}$ Meeting of the $1^{\text {st }}$ Committee of the UN held on $2^{\text {nd }}$ November, 2017, in conference room 4. See also for example: Jones, Catherine. 2015. The Evolution of China's Peacekeeping Role, in David Curran, Larry Roeder and Robert Zuber (eds) New Directions and Opportunities for Peacekeeping: Expanding Stakeholders and Regional Arrangements (Springer) pp.109-127, pp.119-120.

${ }^{26}$ Participant observation by the author, October to November 2017.

${ }^{27}$ Wikileaks, 2009. 'PRC/DPRK: China responds with specificity to US draft' Wikileaks, available at https://wikileaks.org/plusd/cables/09BEIJING1434_a.html accessed on 21 November 2017.

${ }^{28}$ Notes on the standards of evidence for the panel of expert's are noted in the introductory materials of each report.

${ }^{29}$ UN Document S/Res 2094( 2013) para.16

${ }^{30}$ In addition, in the Commission Of Inquiry report of the UNHRC into Human Rights in North Korea, China's note verbale (A/HRC/25/63 pp.33-36, $7^{\text {th }}$ Feb 2014) and letter to the Inquiry (A/HRC/25/CRP.1, $7^{\text {th }}$ Feb 2014) make it clear that China doesn't view the report as having collected 'credible evidence'.

${ }^{31}$ UN Document S/PV.5551(2006) p.4

${ }^{32}$ UN Document S/PV.6141(2009) p.3 
${ }^{33}$ Perlez, Jane. 2013. “China says it won’t forsake North Korea, despite support for UN sanctions” New York

Times, March 9, 2013

\section{Bibliography}

Acharya, Amitav. 2018. Constructing Global Order: Agency and Change in World Politics, Cambridge University Press, Cambridge.

Adler, Emmanuel, and Victor Pouliot (eds.). 2011. International Practices, Cambridge University Press: Cambridge, UK.

Adler, Emmanuel and Vincent Pouliot. 2011b. 'International Practices: Introduction and Framework' in Adler, Emmanuel, and Victor Pouliot (eds). 2011. International Practices, Cambridge University Press: Cambridge, UK, pp.3-53.

Adler-Nissen, Rebecca, and Vincent Pouliot. 2014. 'Power in Practice: Negotiating the International Intervention in Libya' European Journal of International Relations, DOI:10.1177/1354066113512702, pp.1-23.

Alderson, Kai. 2001. 'Making sense of socialization' Review of International Studies, 27(3), pp.415-433.

Autesserre, Severine. 2014. Peace and Conflict Resolution and the Everyday Politics of International Intervention. Cambridge University Press: Cambridge, UK.

Author 2015.

Author 2018.

Axelrod, Robert. 1986. 'An Evolutionary Approach to Norms', The American Political Science Review, 80(4) pp.1095-1111.

Barnett, Michael and Martha Finnemore. 2004. Rules for the World: International Organizations in Global Politics, Cornell University Press; Ithaca, USA.

Buzan, Barry. 2004. From International to World Society? English School Theory and the Social Structure of Globalisation Cambridge University Press: Cambridge, UK.

Barry Buzan. 2010. 'China in International Society: Is 'Peaceful Rise' Possible?', Chinese Journal of International Politics, 3(1) pp.5-36.

Beeson, M., \& Li, F. (2016). China's place in regional and global governance: A new world comes into view. Global Policy, 7(4), pp.491-499.

Berger, Andrea, Cameron Trainer, Shea Cotton and Catherine Dill. 2018. 'The Shadow Sector: North Korea's Information technology Networks' CNS Occasional Paper No. 36, published May 2018, p.5.

Berman, Sheri. 2001. 'Ideas, Norms, and Culture in Political Analysis' Comparative Politics, 33(2) pp.231-250.

Biersteker, Thomas J. Marcos Tourinho, and Sue Eckert. 2016. 'Thinking about United Nations Targeted Sanction' in Biersteker, Thomas J., Sue Eckert and Marcos Tourinho, (eds) The impacts and effectiveness of United Nations Action, Cambridge University Press: Cambridge UK 
Bueger, Christian. 2013. 'Practice, Pirates and Coast Guards: The Grand Narrative of Somali Piracy' Third World Quarterly, 34(10), pp.1811-1827.

Bueger, Chirstian. 2014. 'Pathways to Practice: Praxiography and International Politics' European Political Science Review, 6(3), pp.383-406.

Bueger, Christian, and Frank Gadinger. 2015. 'The Play of International Practice' International Studies Quarterly, 59, pp.449-460.

Bull, Hedley. 2002. The Anarchical Society: A Study of Order in World Politics, Columbia University Press: New York.

Clark, Ian. 2014. 'China and International Society: The Power of Norms and the Norms of Power' Chinese Journal of International Politics, 7(3), pp.315-340.

Cortell, Andrew P. and James W. Davis, Jr., 1996. 'How Do International Institutions Matter? The Domestic Impact of International Rules and Norms', International Studies Quarterly, 40(4) pp.451-78.

Cossa, Ralph A and Brad Glosserman. 2012. "The Illogic of China's North Korea Policy" PacNet No.32

Dill, Catherine. 2018. 'A Note on China's Implementation of UNSCR 2375' Arms Control Wonk, blog published on 18May 2018, accessed https://www.armscontrolwonk.com/archive/1205203/a-note-on-chinas-implementation-ofunscr-2375/ on 18 May 2018.

Dosi, Giovanni, Luigi Marengo, Andrea Bassanini, Marco Valente. 1999. 'Norms as Emergent Properties of Adaptive Learning: The Case of Economic Routines' Journal of Evolutionary Economics 9, pp.5-26.

Dunne, Tim. 1998. Inventing International Society: A History of the English School, Palgrave Macmillan, Basingstoke, UK.

Dworkin, Ronald. M. 2004. Law's Empire Hart.

Economy, Elizabeth, and Michael Okensberg (eds.) 1999. China Joins the World: Progress and Prospects, Brookings Institution, Washington D.C.

Ferdinand, Peter, and Wang Jue. 2013. China and the IMF: from Mimicry towards Pragmatic International Institutional Pluralism, International Affairs 89(4) pp.895-910.

Finnemore, Martha. 1996. National Interests in International Society Cornell University Press: Ithaca.

Foot, Rosemary and Walter, Andrew, 2010. China, the United States, and Global Order, Cambridge, Cambridge University Press.

Gilpin, Robert. 1982. War and Change in World Politics Cambridge University Press: Cambridge.

Glanville, Luke. 2010. 'The Antecedents of 'Sovereignty as Responsibility”, European Journal of International Relations, 17(2) pp.233-255. 
Goertz, Gary and Paul F. Diehl. 1992. 'Toward a Theory of International Norms: Some Conceptual and Measurement Issues', The Journal of Conflict Resolution, 36(4) pp.634-64.

Heritier, Adrienne. 2007. 'Theories of Institutional Change', in Adrienne Heritier (eds), Explaining Institutional Change in Europe, Oxford University Press: Oxford, pp.6-67.

Hibbs, Mark. 2012. 'China and DPRK Sanctions - Busting' Arms Control Wonk Blogs, posted June $24^{\text {th }} 2012$ available http://hibbs.armscontrolwonk.com/archive/847/china-and-dprksanctions-busting accessed 5th August 2013

Hirono, Miwa. 2011. 'China's Charm Offensive and Peacekeeping: The Lessons of Cambodia - What Now for Sudan?' International Peacekeeping 18(3) pp.328-343.

Hodgson, Geoffrey M. 'Institutions and Individuals: Interaction and Evolution' Organisational Studies (2007) 28(1) pp.95-116.

Hopf, Ted. 2010. 'The Logic of Habit in International Relations' European Journal of International Relations, 16(4), pp.539-561.

Hurrell, Andrew. 2004. 'Power, Institutions, and the Production of Inequality', in Michael Barnett and Robert Duvall (eds.), Power in Global Governance Cambridge University Press: Cambridge.

Ikenberry, G. John, 2001. After Victory: Institutions, Strategic Restraint, and the Rebuilding of Order after Major Wars, Princeton University Press: Princeton.

Ikenberry, G. John. 2009. 'Liberal Internationalism 3.0: America and the Dilemmas of the Liberal World Order', Perspectives on Politics, 7(1) pp.71-87.

Jakobsen, Linda and Dean Knox. 2010. New Actors in Chinese Foreign Policy Making. SPIRI Policy Paper, No.26 published September 2010, available https://www.files.ethz.ch/isn/120962/SIPRIPP26.pdf accessed 30 ${ }^{\text {th }}$ January 2017

Johnson, Alastair Iain. 2003. 'Is China A Status Quo Power?' International Security, 27(4) pp.5-56.

Johnston, Alastair Iain, Social States: China in International Institutions 1980-2000., Princeton, NJ: Princeton University Press, 2008.

Keohane, Robert. 1988. 'International Institutions: Two Approaches' International Studies Quarterly, Vol. ?, No. ?.

Keohane. Robert. 1989. International Institutions and State Power, Boulder, Colorado.

Kent, Ann E. 2009. Beyond Compliance: China, International Organizations, and Global Security, Stanford University Press: Stanford.

Kent, Ann E., 2010. China, the United Nations and Human Rights: The Limits of Compliance University of Pennsylvania Press: Philadelphia.

Kim, Samuel, 1979. China, the United Nations and World Order, Princeton University Press: Princeton, New Jersey. 
Kuhn, Thomas. 1991. ( ${ }^{\text {rd }}$ Edn.) The Structure of Scientific Revolutions, Chicago University press: Chicago.

Krasner, Stephen D. 1999. Sovereignty: Organized Hypocrisy Princeton University Press: Princeton, N.J.

Kratochwil, F. 1984. The force of prescriptions. International Organization, 38(4), pp.685-708. doi:10.1017/S0020818300026916

Lee, Pak K. Gerald Chan, and Lai-Ha Chan. 2011. 'China in Darfur: Rule-Maker or RuleTaker' Review of International Studies, (2011) 38(2) pp. 423-444.

Lindner, Johannes. 2003. 'Institutional Stability and Change: Two Sides of the Same Coin' Journal of European Public Policy, (2003) 10(6), pp.912-935.

Lowe, Vaughan. 2000. 'Chapter 10: The Politics of Law-Making: Are the Methods and Character of Norm Evolution Changing?', in Michael Byers (ed.), The Role of Law in International Politics: Essays in International Relations and International Law Oxford University Press: Oxford pp.207-27.

Mahoney, James and Kathleen Thelen (eds) 2009. Explaining Institutional Change: Ambiguity, Agency and Power, Cambridge University Press: Cambridge.

March, J.G. and J.P. Olsen, 04/09 'The Logic of Appropriatness'. Working Paper WP 04/09, available, http://www.arena.uio.no/publications/papers/wp04_9.pdf accessed August 2018.

Medeiros, Evan S. 2005. 'Strategic Hedging and the Future of Asia-Pacific Stability', The Washington Quarterly, 29(1) pp.145-67.

Morin, Jean-Frederic and E. Richard Gold. 2016. 'International Socialization at the state and individual levels: mixed evidence from intellectual property' Cambridge Review of International Affairs, online first, pp.1-21.

Müller, H. (2004). Arguing, Bargaining and all that: Communicative Action, Rationalist Theory and the Logic of Appropriateness in International Relations. European Journal of International Relations, 10(3), 395-435.

Navari, Cornelia. 2010. 'The Concept of Practice in the English School' European Journal of International Relations, 17(4), pp.611-630.

Neumann, Iver. 2012. At Home with the Diplomats: Inside A European Foreign Ministry, Cornell University Press: Ithaca.

Noland, Marcus. 2009. 'The (non) impact of UN sanctions on North Korea' East-West Centre Working Papers, no.98.

O’Neill, Kate, Jörg Balsiger, and Stacy D. Van Deveer, 2004. 'Actors, Norms, and Impact: Recent International Influence of the Agent-Structure Debate' Annual Review of Political Science 7, pp.149-75.

Philpott, Daniel. 2001. Revolutions in Sovereignty: How Ideas Shaped Modern International Relations, Princeton University Press: Princeton and Oxford. 
Pouliot, Vincent. 2013. 'Methodology: Putting Practice Theory into Practice' in Adler Nilsson, Rebecca (eds.) Bourdieu in International Relations: Rethinking Key Concepts in IR Routledge: Abingdon.

Pouliot, Vincent and Jeremie Cornut. 2015. 'Practice Theory and the Study of Diplomacy: A Research Agenda', Cooperation and Conflict, 50(3), pp.297-315.

PRC Position Paper on UN Reforms, Section 6, $7^{\text {th }}$ June 2005, available http://www.china.org.cn/english/government/131308.htm\#4

Ringmar, Erik. 2014. 'The search for dialogue as a hindrance to understanding: practices as inter-paradigmatic research program' International Theory 6(1), pp.1-27.

Risse, Thomas. 2000. "'Let's Argue!": Communicative Action in World Politics', International Organization, 54(1) pp.1-39.

Reich, Simon. 2010. Global Norms, American Sponsorship and the Emerging Patterns of World Politics, Palgrave Macmillan: Basingstoke, 2010.

Reilly, James and Bates Gill, 2000. 'Sovereignty, Intervention and Peacekeeping: The View from Beijing', Survival, 42(3) pp.41-60.

Reilly, James. 2012. 'Norm-Taker or Norm-Maker? Chinese Aid in Southeast Asia,' Journal of Contemporary China, 21, pp.71-91.

Rennack, Dianne E. 2006. 'North Korea: Economic Sanctions' CRS Report for Congress, updated 17 October 2006, available https://fas.org/sgp/crs/row/RL31696.pdf accessed 3 June 2019.

Reus-Smit, Christian. 2003. 'The Constitutional Structure of International Society and the Nature of Fundamental Institutions' International Organization. 51(4) pp.555-589.

Ruggie, John Gerard. 1998. Constructing the World Polity: Essays on International Institutionalization Routledge: London.

Schimmelfennig, F. (2000). International Socialization in the New Europe: Rational Action in an Institutional Environment. European Journal of International Relations, 6(1), 109-139.

Shannon, Vaughan P. 2000. 'Norms are What States Make of Them: The Political Psychology of Norm Violation' International Studies Quarterly, 44(2) pp.293-316.

Sonya Sceats with Shaun Breslin. 2012. China and the International Human Rights System London: Chatham House.

Sending, Ole Jacob. 2002. 'Constitution, Choice and Change: Problems with the 'Logic of Appropriateness' and Its Use in Constructivist Theory', European Journal of International Relations, 8(4) pp.443-70.

Smith, A.D 1973. The Concept of Social Change: A Critique of the Functionalist Theory of Social Change Routledge and Kegan Paul: London and Boston.

Thies, Cameron. 2003. 'Sense and Sensibility in the study of socialisation: A reply to Kai Alderson' Review of International Studies, 29(4), pp.543-550. 
UN Document, A/72/525, of 13 October 2017, section III.

Wang, Hongying \& XueYing Hu. 2017. China's "Going-Out" Strategy and Corporate Social Responsibility: Preliminary Evidence of a "Boomerang Effect", Journal of Contemporary China, 26:108, pp.820-833.

Weisser, Florian. 2014. 'Practices, Politics, Performativities: Documents in the International Negotiations on Climate Change', Political Geography, 20 pp.46-55.

Wendt, Alexander. 2010. Social Theory of International Politics, Cambridge University Press: Cambridge, UK.

Wikileaks. 2007. 'Chinese provide case briefings and criticises US sanctions in afternoon Nonpro dialogue session' available https://wikileaks.org/plusd/cables/07BEIJING5361_a.html text dated 15th August 2007, last accessed 13 ${ }^{\text {th }}$ October 2016.

Wikileaks, 2009a. 'China unlikely to fully implement sanctions on North Korea: A view from Shanghai' original sent on 12 June 2009, published on Wikileaks https://wikileaks.org/plusd/cables/09SHANGHAI257_a.html accessed on 21 November 2017.

Wikileaks. 2009b. 'DPRK: Expert Panel Delayed by Squabble over representation' available at https://wikileaks.org/plusd/cables/09USUNNEWYORK718 a.html accessed 13th October $\underline{2016}$.

Wikileaks, 2010. 'G3* - CHINA/DPRK/US - North Korea Circumventing UN Sanctions With China's Help, U.S. Report Says' Wikileaks, released on 19 October 2012, available, https://wikileaks.org/gifiles/docs/17/1799178_g3-china-dprk-us-north-korea-circumventingun-sanctions-with.html accessed 21 November 2017.

Wilson, J. D. 2019. 'The evolution of China's Asian Infrastructure Investment Bank: from a revisionist to status-seeking agenda.' International Relations of the Asia-Pacific, 19, pp.147176.

Wuthnow, Joel. 2013. Chinese Diplomacy and the UN Security Council, Routledge: London.

$\mathrm{Xu}$, Beina and Bajoria, Jayshree, 2014, 'China North Korea Relationship, updated August 22 2014.

Yang, Suzanne Xiao. 2013. China and the UN Security Council Decision Making on Iraq. Routledge: Abingdon.

Zaum, Dominik. 2007. The Sovereignty Paradox Oxford University Press: Oxford. 